\title{
fourierismo no brasil meridional: a saga do falanstério do saí (1841-1844)^
}

\author{
Hoyêdo Nunes Lins \\ Professor do Departamento de Ciências Econômicas e do Programa de Pós-Graduação em Eco- \\ nomia da Universidade Federal de Santa Catarina
}

RESUMO

$\mathrm{O}$ artigo aborda a efêmera iniciativa de colonização da Península do Saí (nordeste da então Província de Santa Catarina) por socialistas utópicos franceses, na primeira metade dos anos de 1840. Com base em fontes históricas, mas também explorando a bibliografia disponível sobre o tema, o objetivo é captar a trajetória dessa experiência e compreender a sua derrocada. $\mathrm{O}$ estudo mostra que, apesar do entusiasmo inicialmente provocado, o processo de colonização nasceu em meio à discórdia. Os primeiros desentendimentos provocaram quebra de confiança em todos os níveis: entre os próprios colonos, entre as lideranças e no âmbito do governo tanto central quanto provincial. Mas a incerteza sobre o escoamento dos produtos da colônia pareceu determinante. Sem o envolvimento do governo como comprador, mostrava-se insustentável, por exemplo, a fabricação de máquinas a vapor em local tão distante das áreas de maior concentração populacional no país.

Palavras-chave: Falanstério do Saí, colonização industrial, Província de Santa Catarina, socialismo utópico, utopismo fourierista

\begin{abstract}
The article looks at the short initiative of creating an industrial colony in the Saí Peninsula (Northeast of the Province of Santa Catarina) by French utopian socialists in the first half of the 1840s. Based on historical sources but also on the available literature on the subject, the main intention is to apprehend the course and specially the decline of that experience. The research shows that, despite the enthusiasm about the first movements, the process was surrounded by discontentment since the beginning. The initial conflicts led to lack of confidence at different levels: among the settlers, among their leaders and at both the central and provincial government. But what seemed actually determining were the uncertainties concerning commercialization. Without government involvement as a buyer, manufacturing of, for instance, steam machines looked unsustainable, due to distance from more populated regions of the country.
\end{abstract}

Keywords: Phalanstere of Saí, industrial colonization, Province of Santa Catarina, utopian socialism, Fourier's utopian ideas

\section{Introdução}

O assunto deste artigo é a iniciativa de criação, nos anos 40 do século XIX, de uma colônia industrial no nordeste da então Província de

* Submetido em maio, 2009; aceito em abril, 2010. 
Santa Catarina, mais precisamente na Península do Saí, no atual Município de São Francisco do Sul. Os participantes eram imigrantes franceses, seguidores das ideias do socialista utópico Fourier. O fluxo de colonização teve início no final de 1841 e desdobrou-se em algumas chegadas, que se repetiram até 1844 , período em que a colônia já era referida em meios institucionais da província com uma indignada mistura de frustração e reprovação, um sentimento que se intensificou no decorrer do tempo.

O objetivo da pesquisa é descortinar a trajetória da experiência, de efêmera duração, procurando compreender principalmente as condições da sua derrocada. Essa questão é instigante, pois outras experiências de colonização baseadas na vinda de estrangeiros, protagonizadas à mesma época na Província de Santa Catarina, mostravam-se bem sucedidas. De fato, em discurso proferido no início de 1844, na Assembléia Legislativa, o presidente provincial assinalou: "Prosperam as colônias estabelecidas na província, menos a do Saí, que hoje, com nove homens, e sem estabelecimento algum, quer agrícola, quer industrial, toca a sua completa aniquilação [...]"1.

Utiliza-se como base, além da bibliografia acadêmica e não acadêmica obtida, um acervo de documentos produzidos tanto por participantes da experiência colonizadora quanto por agentes externos, vinculados ou não à administração da província. Esses documentos têm origens diversas. Uma parte veio da Biblioteca Nacional, como as matérias publicadas - entre elas, diversas cartas - pelo Jornal do Commercio, do Rio de Janeiro, entre 1840 e 1843. Outra parte, referente aos discursos dos presidentes da província no período de 1836 a 1852, foi obtida no Center for Research Libraries. Utilizou-se também material do Arquivo Público de Santa Catarina (APSC) e do Arquivo Histórico de Joinville $(\mathrm{AHJ})^{2}$.

A trajetória da colonização no Saí aqui apresentada é a que aflora desses documentos. Quer dizer, a história em questão resulta do manu-

1 Fala do Presidente da Província de Santa Catarina na Assembleia Legislativa, em 01/03/1844. Disponível em <//brazil.crl.edu/bsd/bsd/930/índex.html $>$.

2 Vários documentos desses arquivos foram consultados no acervo da professora Raquel S. Thiago, da Universidade da Região de Joinville, autora de um livro sobre esse tema (S. Thiago, 1995). O autor agradece a gentileza da professora em disponibilizar esse material. 
seio de tais documentos. De algum modo, esse entendimento guarda sintonia com o que pensa Michel Foucault (2005:294) sobre história e documentos:" [q]uando os historiadores tratam os documentos, eles não visam a interpretá-los, ou seja, não procuram por trás ou além deles um sentido escondido". A história, na verdade,

[...] é o trabalho e a utilização de uma materialidade documental (livros, textos, narrações, registros, atas, edificios, instituições regulamentos, técnicas, objetos, costumes, etc.) que apresenta sempre e em toda a parte, em qualquer sociedade, formas de permanências, quer espontâneas, quer organizadas. O documento não é o feliz instrumento de uma história que seria em si mesma, e de pleno direito, memória; a história é, para a sociedade, uma certa maneira de dar status e elaboração à massa documental de que ela não se separa (Ibidem, pp.7-8, em itálico no original).

Não é ocioso assinalar que esses documentos se referem a acontecimento fortemente marcado pelo contexto da sua ocorrência. Em longa carta publicada pelo Jornal do Commercio em 17 de dezembro de 1840, o Dr. Mure, médico francês que lideraria o processo colonizador a partir do ano seguinte, informa a sua intenção quanto à colônia industrial e fornece detalhes a respeito da idealizada iniciativa. O contexto material transparece numa frase como esta:

No estado de sofrimento e de contínuas crises em que se acha há alguns anos a indústria da Europa, a necessidade da emigração é ali tão vivamente sentida quanto a de atrair colonos o é nos vastos impérios que começam a vida de nações no continente da América ${ }^{3}$.

A inspiração teórica e ideológica do empreendimento pode ser captada no seguinte trecho da mesma carta:

[...] se a organização do trabalho não for mudada, se as relações dos produtores entre si não forem estabelecidas sobre outra base, tereis em breve em redor de vós as bancarrotas, as crises da indústria, as astúcias da traficância, o sacrifício do obreiro ao capitalista, a guerra dos trabalhadores de todas

3 Carta do Dr. Mure publicada pelo Jornal do Commercio (RJ) em 17/12/1840, p. 2, na Coluna "Colonização". (Biblioteca Nacional). 
as classes, úlcera profunda e incurável que corrói essas nações na aparência tão ricas e tão florescentes que residem do outro lado do Atlântico. [...] É, pois, ao princípio da associação [...] que devemos pedir a solução das dificuldades que tivermos de encontrar ${ }^{4}$ (negrito adicionado à citação).

A matriz desse entendimento aparece assinalada no discurso do Dr. Mure a D. Pedro II, em 18 de dezembro de 1841, na ocasião da chegada ao Rio de Janeiro do primeiro grupo de colonos franceses. Agradecendo a hospitalidade concedida um ano antes, quando o médico dirigiuse ao país, no intuito de encontrar meios que possibilitassem desenvolver um projeto de colonização nos moldes contemplados, e agradecendo também a receptividade do governo imperial, que viabilizara a iniciativa, Mure declarou:

Le Brésil ne sera donc pas en arrière des nations les plus éclairées du globe, qui, en ce moment, prenant Fourier pour guide, cherchent à résoudre le grand problème de l'organisation du travail et de la pacification des intérêts $[\ldots]^{5}$.

Referência explícita a Fourier apareceria de novo seis meses mais tarde, em carta redigida por Mure já na colônia, em 6 de junho de 1842, com descrição das realizações dos primeiros meses. O trecho seguinte (essa carta foi publicada pelo Jornal do Commercio em 23 de junho de 1842) é sugestivo:

Nunca se levou a efeito um grande movimento de emigração sem um impulso moral, sem uma agitação intelectual que a precedesse. Em uma palavra, os corpos não se agitam senão depois de estarem agitados os espíritos. Não há efeito sem causa. [...] [A] revolução francesa foi como a da Inglaterra. Destruiu muito e criou pouco. Prometeu muito e realizou

Ibidem.

5 ["O Brasil não estará, portanto, atrás das nações mais esclarecidas do globo, as quais, nesse momento, tomando Fourier por guia, buscam resolver o grande problema da organização do trabalho e da pacificação dos interesses [...]". Discours adressé à S. M. L'Empereur D. Pedro II, le 18 décembre 1841, par le Dr. Mure, à l'occasion de la présentation des premiers colons industriels. Jornal do Commercio (RJ), p. 1, 21/12/1841 (Biblioteca Nacional). 
pouco, mas deixou nos espíritos grandes preceitos. Adiantou a ciência da humanidade, legou-nos Fourier e seu sistema ${ }^{6}$.

Tais ingredientes sugerem uma estrutura de texto que, antes de focar a trajetória da experiência colonizadora, conceda destaque ao seu substrato teórico e ao respectivo contexto material. Assim discorre-se, pela ordem, sobre a inspiração fourierista dos colonizadores, sobre a situação na Europa (contexto imediato da iniciativa e do próprio sistema de Fourier) e no Brasil, na primeira metade do século XIX, e, na maior parte do artigo, sobre a colonização na Península do Saí.

\section{Fourierismo, matriz da colonização francesa no Saí}

O francês François Marie Charles Fourier é uma das três personalidades incluídas por Marx e Engels (1973) em seção do Manifesto do Partido Comunista, intitulada "O socialismo e o comunismo críticos e utópicos". As outras são Claude Henri de Saint-Simon, também francês, e Robert Owen, britânico. Os autores do Manifesto não tergiversam na crítica às ideias professadas pelo grupo, indicativas, para os primeiros, de uma escassa percepção das possibilidades de emancipação do proletariado. Para Marx e Engels, esses socialistas utópicos "rejeitam toda ação política, notadamente toda ação revolucionária, [...] querem alcançar seu objetivo por vias pacíficas e [...] tentam abrir caminho ao novo evangelho social através de pequenas experiências [...]" (Ibidem, p. 49).

Mas não é só de condenação que se trata no Manifesto, pois não se deixa de reconhecer nos utopistas uma fecunda capacidade analítica e crítica. Em que pesem as suas limitações, escrevem Marx e Engels, esses pensadores "atacam todos os fundamentos da sociedade estabelecida. Essa é a razão pela qual produziram material de um valor enorme para abrir o espírito dos trabalhadores" (p. 50).

A combinação de crítica contundente e reconhecimento de profundidade no pensamento perpassa outros escritos canônicos do marxismo sobre os utopistas. O mais representativo é Socialismo Utópico e Socialismo

6 Carta do Dr. Mure publicada pelo Jornal do Commercio (RJ) em 23/06/1842, p. 1 (Biblioteca Nacional). 
Científico, publicado por Engels em 1880 (ENGELS, 1974). O ataque ao pensamento utópico permaneceu, como indica este trecho:"esses novos sistemas sociais estavam de antemão condenados à utopia. Quanto mais eram detalhadamente elaborados, mais se perdiam na fantasia pura" (p. 35). Mas o reconhecimento da densidade também foi mantido:

[...] o socialismo teórico alemão não esquecerá jamais que se alçou nos ombros de Saint-Simon, Fourier e Owen, três homens que, malgrado todas as suas idéias quiméricas e suas visões utópicas, encontram-se entre os maiores cérebros de todos os tempos [...] (p. 38).

Saint-Simon, Owen e Fourier não formam conjunto homogêneo quanto à teorização sobre o avanço social e às iniciativas de reforma. Há “no socialismo 'utópico' [...] um elemento de edificação e planejamento orgânico que procura reestruturar a sociedade e, isso, não após a ‘extinção’ da ditadura do proletariado num futuro indeterminado, mas aqui e agora, a partir das condições atuais” (BUBER, 1971:27). Porém, além do voluntarismo, muitas vezes traduzido em experiências de "sociedades socialistas em miniatura e dentro de redomas [...] [que visavam] propagar-se e dominar [...] a totalidade do corpo social" (PETITFILS, 1977:12), não há maiores coincidências entre as contribuições.

Descendente de uma antiga linhagem nobre, o que lhe garantiu uma educação de alta qualidade, Saint-Simon foi o utopista que melhor compreendeu a maré montante da sociedade industrial e avaliou as suas implicações. Para ele, o sentido da história era uma inapelável (ainda que cíclica) progressão da indústria, percepção que o inspirou a imaginar a sociedade do futuro nos moldes do funcionamento do sistema industrial em consolidação. Consciente dos perigos do liberalismo e fiel à ideia de que "na sociedade as partes deviam subordinar-se ao todo" (WILSON, 1987:82), Saint-Simon exaltou a importância do conhecimento científico para o avanço social e preconizou uma função primordial para os industriais - entendidos como todos os que contribuem para a formação da riqueza, de trabalhadores a empresários - na estrutura da sociedade (hierarquizada pelo critério do mérito), em detrimento dos ociosos, representados pelos privilegiados (como os nobres e os membros do alto clero) e por aqueles que não se envolvem na produção e no comércio. A utopia saint-simonista inscreve-se nas expectativas de- 
rivadas de tal visão sobre a sociedade: os homens se aproximariam por meio das relações econômicas, o exercício do poder pelos industriais seria pacífico, em quadro de ampla concórdia na sociedade, e o papel do Estado sofreria, por conta disso, forte encolhimento, quiçá desaparecimento.

Owen nada tinha de aristocrata, e sua aprendizagem não transcendeu a prática da fabricação de tecidos, mas suas qualidades individuais e a expansão econômica da Grã-Bretanha no final do século XVIII favoreceram-lhe sucesso como produtor têxtil. Sobretudo, adquiriu reputação de grande filantropo, como empresário adepto de medidas como redução do tempo de trabalho, introdução de condições de trabalho mais seguras e menos insalubres, oferta de possibilidades para educação tanto infantil quanto adulta e eliminação do trabalho para crianças. Mas suas ideias iam além das que nutriam essa conduta de "grande patrão esclarecido" (PETITFILS, 1977:74). Acreditava que certos ambientes poderiam melhorar o comportamento humano, ainda que em ações inicialmente restritas a pequenas experiências sociais. Para ele, a piora da situação econômica e social na Grã-Bretanha, após a guerra de 17921815 com a França, espelhava o funcionamento da economia, fonte de grande "concorrência" entre máquinas e trabalhadores, com redução dos salários e do consumo e aumento da pobreza. Daí a necessidade de reconstruir a sociedade em outras bases, com realce para o associativismo e o cooperativismo na esfera das relações comunitárias - em vilas-modelo ou vilas de cooperação - sob o signo da reciprocidade, da propriedade mútua, da aproximação entre as atividades agrícolas e as industriais, da harmonia e da solidariedade como principal cimento das relações.

Fourier não teve origem nobre como Saint-Simon, ou humilde como Owen. Filho de um negociante que também exercia funções ligadas ao Estado, foi encaminhado contra a sua vontade para atividades comerciais. Numa França imersa nas turbulências subsequentes ao fim do Ancien Régime, isso lhe permitiu experiências decisivas para a formação. Adjetivos como compulsivo, contraditório, delirante, maníaco, ranzinza, teimoso e confuso foram utilizados para referir à sua personalidade e ao seu comportamento ${ }^{7}$. Mas sua crítica das condições sociais

7 Referências biográficas sobre Fourier podem ser encontradas em Beecher (1990). 
foi reconhecida como penetrante por Engels (1974:38), pois Fourier, "um dos maiores satiristas de todos os tempos, [...] desvela sem piedade a miséria material e moral do mundo burguês e a confronta com as promessas adocicadas dos filósofos das luzes sobre a sociedade [...]".

Sua obra é marcada por traços muito pessoais e apresenta, numa retórica cheia de neologismos, os contornos do que é designado como "teoria da atração passional". Fourier qualificou como período da "civilização" (após sequência contendo os períodos do "éden”, da "selvageria", do "patriarcado" e da "barbárie") o estágio então vivido pela humanidade. Apesar da denominação, a "civilização" caracterizava-se, segundo o autor, pela desordem geral e pelo sofrimento causado pela miséria, envolvendo desemprego e baixos salários. Reorganizar uma indústria "fragmentada", tida como principal origem desses problemas, e superar a "fragmentação social”, associada também à existência da família monogâmica - considerada antinatural, propícia ao rebaixamento da condição feminina e apta a provocar ou aprofundar o individualismo e o egoísmo - constituíam providência indispensável para Fourier. Tal objetivo deveria ser buscado em sistema cujo alicerce básico era a "atração passional", uma ideia ligada ao entendimento de que o "prazer é o objetivo final da vida: nenhuma de suas manifestações deve ser afastada ou proibida" (PETITFILS, 1977:96). O sonho de Fourier era nada menos que a liberdade total, o desatamento das paixões, a ausência de censura - principalmente da autocensura e do autocerceamento - tudo com vistas a alcançar objetivos elevados.

Após a "civilização", a humanidade evoluiria rumo à "harmonia", uma fase idílica, alegre, desprovida de aborrecimentos e com trabalhos atraentes: numa palavra, o reino da "ordem passional". Que engenharia poderia sustentar tal progressão? Em livro que sintetiza a sua teoria, publicado pela primeira vez em 1829, Fourier (1989:38) assinala que o "estudo da atração passional conduz diretamente ao descobrimento do mecanismo societário [...]" capaz de "criar a atração industrial: ver-se-á nela os [...] ociosos, inclusive os janotas ridículos, estarem de pé às quatro da manhã, tanto no inverno como no verão, para se entregarem com ardor aos trabalhos úteis [...]" (Ibidem, p. 37). Como núcleo da organização societária figuraria o "falanstério" - termo cunhado por Fourier com a contração entre 'falange' e 'monastério' - uma edificação de uso diversificado e comum. Em tais experiências, a economia teria um 
perfil notadamente agrícola, mesmo que atividades manufatureiras fossem também contempladas, e os trabalhos seriam organizados em "séries passionais", onde o engajamento seria livre, espontâneo e presidido pelo interesse de cada pessoa nas atividades, com participação franqueada em tantas séries quantas se desejasse.

Esse é, grosso modo, o sistema fourierista, aludido pelo Dr. Mure na correspondência anteriormente citada. E essa é a sua utopia: a instalação de "falanstérios", com o impregnado sentido de reforma social, contaminaria a sociedade e, mesmo que na forma exposta esse "sistema não se [...] [ocupasse] das relações entre as unidades” (BUBER, 1971:32), acabaria por suprimir a ordem capitalista. Os seguidores de Fourier se encarregaram de testar aquelas ideias, multiplicando experiências na Europa e em outros continentes ${ }^{8}$. Entre essas figurou a tentativa dos franceses na Península do Saí, objeto deste artigo. O que se falou do sistema fourierista, assinale-se, é ilustrativo do que estava em jogo para os idealizadores desse projeto de colonização. Com efeito, para Fourier (1989),

O industrialismo é a mais recente de nossas quimeras científicas; é a mania de produzir confusamente, [...] sem nenhum método de retribuição proporcional, sem nenhuma garantia, para o produtor ou o assalariado, de participar no aumento de sua riqueza [...] (p. 63).

$\mathrm{Na}$ tão elogiada Inglaterra, a metade da população encontra-se [...] a trabalhar dezesseis horas por dia, uma parte inclusive em oficinas infectadas, para ganhar sete soldos de França, em um país onde a subsistência é mais custosa que na França (p. 44-45 - em itálico no original).

Os operários franceses são tão miseráveis que nas províncias de alta indústria [...] os camponeses, em suas choças de terra, não têm cama; fazem para si um leito com folhas secas que, durante o inverno, convertem-se em esterco cheio de vermes [...]. O alimento nessas choças é da mesma elegância que o mobiliário (p. 65).

[Daí que aos] abusos da indústria [é preciso contrapor a] [...] política societária, que tem por base a atração industrial, a repartição proporcional, a economia de movimentos, o equilíbrio da população e outras regras das

8 A presença do fourierismo nos Estados Unidos, no século XIX, é abordada por Guarneri (1994). 
quais se distancia em todos os sentidos o sistema industrialista de produção desordenada e sem nenhuma garantia de justiça distributiva (p. 63).

Que realidade é captada pelo termo "industrialismo", na maneira utilizada por Fourier?

\section{Conjunturas geral e específica da iniciativa de colonização no Saí}

No final do século XVIII e início do XIX, importantes mudanças econômicas e sociais foram observadas no centro do sistema mundial. A Holanda teve consolidada a perda da sua liderança econômica para a Grã-Bretanha devido ao crescente poderio comercial e ao progresso técnico e tecnológico, em setores industriais chave como o têxtil (de algodão) e a manufatura de ferro, exibidos pela segunda. No plano político, a Revolução Francesa afetou consideravelmente a situação em diferentes países, uma influência que se estendeu às décadas subsequentes.

O quadro geral era de crescimento econômico. De fato, Kondratieff (1949) situou, na virada para o século XIX, a fase ascendente do que foi por ele identificado como primeiro ciclo longo da economia capitalista. E Maddison (1982), embora reconhecendo a precariedade dos dados referentes ao período anterior a 1870, concluiu que desde 1820 os principais países europeus, entre eles, destacadamente, a Grã-Bretanha, se engajaram num crescimento econômico mais rápido e sustentado do que antes.

As expressões "industrialismo" e "abusos da indústria", presentes nas considerações de Fourier sobre os problemas vividos pelos trabalhadores, remetem ao substrato da conjuntura econômica daquela virada de século. Trata-se do conjunto de mudanças, observadas precocemente e de forma mais clara na Grã-Bretanha, enfeixadas no que se convencionou chamar de "revolução industrial". Assinale-se que, na forma costumeiramente utilizada, essa expressão capta a intensificação das transformações produtivas vivenciadas no século XVIII, inscrita, ela própria, numa sequência muito mais longa de acontecimentos importantes no campo da produção manufatureira (MANTOUX, 1962). 
São mudanças que, segundo Landes (1994), não se restringiram à introdução de máquinas e novas técnicas na produção industrial (a têxtil à frente) e aos grandes avanços na mecanização, no uso de energia de origem não humana ou animal e na obtenção e preparação de matériasprimas. Para esse autor, a principal particularidade era a "congregação de grandes corpos de trabalhadores num único lugar, para ali executarem suas tarefas sob supervisão e com disciplina; [...] em suma, [...] [o] que se tornou conhecido como sistema fabril" (p. 120).

As consequências sociais foram dramáticas. Observando a realidade de Manchester, Engels (1985) produziu um pungente relato das condições dos trabalhadores na década de 1840. De sua parte, Marx discorreu sobre os reflexos da mecanização em termos de apropriação, pelo capital, de forças de trabalho adicionais (mulheres, crianças), de alongamento da jornada de trabalho e de intensificação do trabalho, antes de denunciar o "uso abusivo do maquinismo para transformar o trabalhador, desde a sua mais tenra infância, em parcela de uma máquina que faz, ela própria, parte de uma outra" (MARX, 1982:403). Mesmo Landes (1994:12), entusiasmado com os "novos cenários de conforto e prosperidade para todos os homens [abertos pela mecanização]", admitiu que "as vítimas da Revolução Industrial foram contadas às centenas de milhares, ou mesmo aos milhões [...]" (Ibidem).

Esses processos foram observados principalmente na Grã-Bretanha, líder nas mudanças tecnológicas mais intensas no final do século XVIII. Mas outros países europeus também vivenciaram essas transformações, ainda que com defasagem temporal. A França foi um dos que exibiram essas modificações, embora isso tenha ocorrido com alguma lentidão: em 1847, apesar de um número de máquinas a vapor muito menor do que na Inglaterra, suas grandes fábricas usavam mulheres e crianças na proporção de $25 \%$ e $15 \%$, pela ordem, do contingente total empregado (BOISSONAT, 1982).

Mas a situação desses dois países deve ser colocada em perspectiva, invocando-se a disputa que travaram pela hegemonia mundial no século XVIII. Foi a Grã-Bretanha que, entre 1780 e 1840, logrou alcançar o maior destaque na produção industrial de grande escala, com mecanização intensa e maiores benefícios econômicos. A explicação reside no notável crescimento do mercado britânico em nível mundial, a reboque da sua expansão naval e colonial durante o século XVIII. Isso repercutiu 
em onda de inovações particularmente intensa na Grã-Bretanha, proporcionando-lhe um grande salto de eficiência produtiva na década de 1780, sobretudo na indústria têxtil de algodão (WALLERSTEIN, 1998). A perda de posição na disputa pela hegemonia fez a elite francesa introduzir medidas de fortalecimento da agricultura e da indústria, em tentativa de catch up, tendo como principal elemento a abertura do comércio colonial em 1784, na expectativa de aumentar a arrecadação de impostos (direitos alfandegários) e fortalecer as finanças públicas. A frustração desses objetivos levou o país a firmar tratado comercial com a Grã-Bretanha em 1786 (Tratado de Eden), esperando mitigar (pelos impostos) a sua crise financeira e, simultaneamente, modernizar a sua indústria em reação à concorrência britânica. Contudo, a fragilidade relativa do aparelho produtivo francês resultou numa "importação massiva, um 'autêntico dilúvio' de manufaturas de algodão britânicas (e também de outras manufaturas)" (WALLERSTEIN, 1998:125). A decorrente degradação das condições econômicas e sociais conduziram à Revolução Francesa, em meio à incapacidade do país para enfrentar a concorrência.

Essa sequência de acontecimentos, que também incluiu os desdobramentos da política econômica na França, posteriormente à Revolução, e as implicações das guerras entre 1792 e 1815, com as malsucedidas tentativas napoleônicas para solapar o comércio externo britânico, resultou numa Grã-Bretanha em situação de potência hegemônica em 1815. As vantagens acumuladas desde 1763 haviam proporcionado supremacia industrial e financeira a esse país, solidificada pela incorporação de bases marítimas que permitiam um controle estratégico em escala global, e outorgavam um amplo e duradouro poderio. Embora entre 1815 e 1840 a França tivesse avançado na modernização da sua indústria, sobretudo a têxtil, isso ocorreu no marco de uma "ruralização" das atividades e no sentido do mercado interno, sem representar ameaça ao comércio exterior britânico.

Esse é o quadro geral em que vicejaram os ideais utópicos de Fourier e de outros socialistas utópicos. "Industrialismo" e "abusos da indústria" referem-se à convergência de processos, implicando mecanização aprofundada e reorganização do trabalho, tendo como síntese o sistema fabril, com os decorrentes problemas sociais. Fourier foi contemporâneo dos principais reflexos da assinalada abertura comer- 
cial francesa, origem (ou pelo menos fator de agravamento) de desestabilização econômica que contribuiu para a deterioração das condições dos trabalhadores. Foi também testemunha das tentativas de impulsão da indústria francesa, no período 1815-1840, traduzidas em "ruralização" da produção. As ideias fourieristas de reforma social estavam, desse modo, fortemente impregnadas pelo que era possível observar na realidade do seu país, no rescaldo da perda da disputa pela liderança mundial. $\mathrm{O}$ mesmo pode ser dito da decisão de emigrar, na década de 1840, de franceses seduzidos pelo propósito de instalar um falanstério no Brasil.

Qual era o quadro vigente no destino da transoceânica iniciativa de colonização, em escala de país e de província?

No período em questão, o Brasil deixara recentemente a condição colonial, na esteira de mudanças deflagradas no calor da disputa pela liderança no centro do sistema mundial: foi a investida de Napoleão sobre a Península Ibérica que provocou a transferência da corte portuguesa para o Brasil, inaugurando a sucessão de acontecimentos que culminou na Independência. Todavia, o otimismo do início do século XIX diluiu-se em face das crescentes dificuldades econômicas e políticas das primeiras décadas de vida independente, agravadas pela dramática fragilidade financeira do governo central e pela consequente erosão da sua autoridade, refletida em escalada de revoltas e convulsões sociais em diferentes regiões (FURTADO, 1987).

Ora, em contexto no qual os movimentos básicos da economia assumiam não mais do que "a forma específica de diversificação da atividade produtiva, no interior da fazenda de escravos [...]” (RANGEL, 1981:21 - em itálico no original), as promessas ligadas à criação de focos de atividade industrial haveriam de exercer uma inegável sedução no Brasil.

Note-se que a percepção desse aspecto pelo Dr. Mure e seus sócios provavelmente influenciou a própria confecção do projeto, que se chamava "colônia industrial”, uma denominação pouco sintonizada com o ideário de Fourier, crítico contundente da atividade industrial. Essa percepção influenciou o desenho do empreendimento e também lubrificou, ao que parece, a sua aceitação pelas autoridades brasileiras.

$\mathrm{Na}$ já mencionada carta de apresentação do projeto, o Dr. Mure listou as especialidades dos integrantes da iniciativa colonizadora e exaltou as suas habilidades individuais quanto à criação, à adaptação e 
ao uso de máquinas de diferentes tipos. "Pela reunião de tais meios", sublinhou, "começaria a realizar-se a grande e fecunda aplicação das forças mecânicas à agricultura" ". $\mathrm{Na}$ argumentação, o médico tocava estrategicamente em tema de grande apelo no país naquele período: o trabalho escravo e as implicações da sua extinção. "Assim ficaria resolvido o grande problema do cativeiro, e sair-se-ia desse fatal dilema que, de um lado, rejeita o tráfico de africanos e, de outro, estabelece a impossibilidade de cultivo das regiões inter-tropicais pela raça branca" (Ibidem).

Esses acenos tiveram consequências. Três dias após a apresentação a D. Pedro II dos cem primeiros colonos franceses chegados ao Rio de Janeiro, o Jornal do Commercio concluiu editorial manifestando entusiasmada esperança de que o Brasil pudesse testemunhar um proficuo "espetáculo nessa terra do Saí, onde se vai tentar a grande experiência da organização do trabalho!" 10 . A eloquência não se revelava menor na mensagem dirigida ao imperador: "Possa ela [a experiência] servir de magnífico prelúdio a todas as prosperidades e venturas do seu reinado!" (Ibidem). A iniciativa era cercada de indisfarçável otimismo. Em outro editorial, o Jornal do Commercio indagava se a utopia fourierista no Sul do Brasil se revelaria frustrada ou se daria bons frutos. Eis a posição exibida: se a colonização industrial no Saí for bem sucedida,

[...] a prosperidade da nossa pátria terá dado um grande passo para diante: na Europa toda a classe que sofre tem os olhos fitos no Saí; prospere a colônia, e todos esses escravos dos capitais, todas essas vítimas que um trabalho contínuo superior às forças humanas não preserva da miséria, trar-nos-ão seus braços, sua indústria. Se não prosperar, se o sistema desse socialista for tão quimérico como o dos mais, ainda assim lucraremos: homens industriosos, afeitos ao trabalho, morigerados, terão vindo aumentar nossa população. Recomendada por tão faustos auspícios, a colônia do Saí $[\ldots]$ merece todas as simpatias do patriotismo $[\ldots]^{11}$.

9 Carta do Dr. Mure publicada pelo Jornal do Commercio (RJ) em 17/12/1840, p. 2-3, na Coluna "Colonização" (Biblioteca Nacional).

10 Editorial do Jornal do Commercio (RJ), de 21/12/1841:1, sob o título "Colonização Industrial" (Biblioteca Nacional).

11 Ibidem, 24/12/1841:2, sob o título “A colônia societária” (Biblioteca Nacional). 
A receptividade que o empreendimento angariou no governo brasileiro adquire maior sentido quando considerada no interior desse quadro. Perante os problemas então vivenciados, as possibilidades sinalizadas com base na instalação de núcleos de atividade industrial - inclusive com a prometida fabricação de máquinas a vapor - configuraram atração irresistível, tanto que a roupagem socialista da proposta, que poderia suscitar insanáveis resistências numa elite de latifundiários escravistas, acabou não representando qualquer empecilho realmente incontornável. A rigor, no Brasil do Segundo Reinado, o utopismo fourierista não parece ter sido encarado pela camada dirigente como algo distinto de um bom e grande negócio, fundamentalmente.

A situação não era distinta na Província de Santa Catarina. Nos altos círculos políticos havia plena clareza sobre as carências locais.Vejam-se os termos do discurso do presidente da província aos deputados, em 5 de abril de 1836:

Já começastes, senhores, a legislar sobre o estabelecimento de colônias, e eu reclamo a vossa atenção sobre este [...] assunto, que carece de medidas mais amplas. A natureza, entre os dons de que foi pródiga com este país abençoado, o favoreceu com um clima, além de benigno, próprio para quase todas as produções de ambos os hemisférios. A população, porém, não é proporcionada à extensão do território; faltam-nos braços que façam valer este torrão precioso, até agora em grande parte improdutivo por inculto, e falta-nos também o socorro das artes para o uso e emprego de máquinas que ajudem e facilitem os trabalhos agrícolas. Esses braços, esses auxílios, só nos podem vir da Europa, onde a população superabunda e onde as artes têm chegado ao maior apuro. Cumpre, pois, que por meio de colonizações chamemos ao nosso país homens ativos e industriosos, e supramos com braços livres esses inertes e aviltados pelos ferros da escravidão que nos fornecia o abominável tráfico de carne humana ${ }^{12}$.

O problema da escravidão era considerado especialmente espinhoso. No discurso do ano seguinte, em 1837, o novo presidente assinalou para os deputados:

12 Discurso do Presidente da Província de Santa Catarina na Assembleia Legislativa, em 05/04/1836. Disponível em <http://www.brazil.crl.edu/bsd/bsd/930/índex. html>. 
A nossa indústria agrícola precisa de um impulso benéfico para que não caia em desfalecimento com a cessação do tráfico de escravatura; e este impulso só de vós pode provir, seja pela confecção de leis apropriadas à colonização, seja em conferir meios à Administração para levar à prática tão importante objeto ${ }^{13}$.

O quadro provincial era de grande adversidade em termos econômicos. Por exemplo, em 1838, dizia-se que, antes florescente e muito significativa, a produção de tecidos de algodão e de linho encontrava-se em franco declínio, temendo-se até o seu desaparecimento. Motivo:“[...] tendo crescido o custo de produção, [...] não pode este gênero concorrer com os tecidos estrangeiros, que posto inferiores sejam em duração, vêm ao mercado por preços incomparavelmente inferiores" ${ }^{14}$. No discurso presidencial de março de 1840, a abordagem dos problemas econômicos é mais extensa e ainda mais alarmante do que em ocasiões anteriores ${ }^{15}$. "A indústria fabril, entre nós, não passa de uma frase vazia de sentido" (p. 27), disse o presidente, com ênfase na produção de tecidos, argumentando sobre o dano causado pela concorrência externa; e a afirmação de que "[a] indústria agrícola também não existe entre nós" (Ibidem) antecedeu considerações críticas sobre as dificuldades experimentadas pelos cultivos.

Tendo em vista esse ambiente, não admira que as providências do Governo Imperial relativamente à colonização fourierista no Saí provocassem expectativas favoráveis. $\mathrm{O}$ discurso presidencial aos deputados catarinenses no início de 1842 é eloquente a esse respeito.

Ser-vos-á grato saber que o Governo Imperial, autorizado pela Lei Geral n ${ }^{\circ} 243$, tem mandado fundar uma Colônia Industrial Societária, no Município de S. Francisco, para a qual houve Sua Majestade o Imperador

13 Fala do Presidente da Província de Santa Catarina na Assembléia Legislativa em 01/03/1837:14. Disponível em <http://www.brazil.crl.edu/bsd/bsd/930/índex. html $>$.

14 Discurso do Presidente da Província de Santa Catarina na Assembleia Legislativa 01/03/1838:6. Disponível em <http://www.brazil.crl.edu/bsd/bsd/930/índex. html>.

15 Discurso do Presidente da Província de Santa Catarina na Assembleia Legislativa 01/03/1840. Disponível em <http://www.brazil.crl.edu/bsd/bsd/930/índex. html>. 
por bem conceder duas léguas quadradas de terra devoluta na Península do Saí por Decreto de 11 de dezembro último, que aprovou as condições do contrato celebrado pelo Governo com o Doutor Bento Mure, empresário da colônia, o qual no prazo de um ano deve ter nela quinhentos colonos societários. Os primeiros, em número de cem, chegaram ao seu destino em janeiro deste ano, e tratando-se ainda dos primeiros arranjos para o seu estabelecimento, nada se pode dizer sobre a empresa, da qual, contudo, é permitido esperar que grandes bens resultarão à Província, visto que os societários, devendo ser pessoas de boa morigeração, e dotados de talento e indústria, farão avultar os nossos produtos, e os aperfeiçoamentos materiais que introduzirem servirão de exemplo e de estímulo aos habitantes do país para os imitarem ${ }^{16}$.

\section{A colonização industrial no Saí: o signo da utopia}

Nos primeiros dias de janeiro de 1842, o porto de São Francisco do Sul assistiu ao desembarque de dezenas de franceses que, saindo da cidade de Le Havre, no litoral norte da França, estiveram no Rio de Janeiro, capital do Brasil, por tempo não muito maior que duas semanas. Para bom número de recém-chegados a permanência na vila de São Francisco não foi longa. Apesar de contratempos sobre os quais se falará depois, logo ocorreu o deslocamento para a Península do Saí, localizada no outro lado da Baía da Babitonga. Como assinalado, a Península do Saí fora o local escolhido, com o consentimento e o apoio do governo brasileiro, para a instalação de uma colônia industrial na então Província de Santa Catarina. Os franceses que pisaram o solo catarinense em janeiro de 1842 integravam a leva pioneira de viajantes, entre as cinco que, até o início de 1844, foram sucessivamente organizadas para o trajeto França-Brasil com destino ao Saí (GÜTTLER, 1994).

Mas os movimentos iniciais desse empreendimento foram desencadeados bem antes, numa longa sequência de acontecimentos.

O primeiro aspecto a ser destacado diz respeito ao papel do Dr. Mure, médico nascido em Lyon, partidário da novidade terapêutica que a

\footnotetext{
16 Fala do Presidente da Província de Santa Catarina na Assembleia Legislativa, em 01/03/1842:27. Disponível em <http://www.brazil.crl.edu/bsd/bsd/930/índex. html>.
} 
homeopatia então representava. Convertido às ideias de Fourier, Mure decidira empreender, no âmbito de uma sociedade (denominada Union Industrielle) que criara na França com outros fourieristas, uma iniciativa colonizadora em terras brasileiras. Essa iniciativa não tinha caráter inédito na tentativa de aplicar as ideias de Fourier em termos internacionais ou no envolvimento de Mure com procedimentos do gênero (S.THIAGO, 1995). Tampouco representava a primeira manifestação do pensamento de Fourier no Brasil. De 1840 a 1846, a Província de Pernambuco usufruiu dos serviços do engenheiro francês Vauthier, um fourierista que difundiu o ideário socialista do seu inspirador. "Socialista radical [...], Vauthier concorre para a irradiação das ideias socialistas francesas nesta parte da América. Empresta livros. Indica autores" (FREYRE, 1940:147). Sua passagem pelo Recife encontra-se também documentada em Chacon (1981).

O propósito de criar uma colônia industrial no Brasil fez o Dr. Mure dirigir-se ao país em novembro de 1840 (GÜTTLER, 1994), em cuja capital passou a divulgar suas pretensões. A estratégia incluiu o envio de uma carta ao Jornal do Commercio, do Rio de Janeiro, que a publicou em 17 de dezembro de 1840. Nessa carta, Mure discorre sobre diferentes aspectos do empreendimento almejado.

- A base seria o princípio associativo, presente no âmbito da produção e em outras esferas: por exemplo, uma módica dedução do fruto do trabalho de cada colono permitiria operar um fundo para cobrir situações de doença, de falta ao trabalho e exigências da velhice, além de garantir, independentemente de necessidade particular, os gastos das famílias com a educação dos filhos;

- a educação seria integrada e orientada à formação para o trabalho, respeitando-se as aptidões; as interferências familiares nas carreiras dos filhos (visando formá-los médicos ou advogados, por exemplo) seriam coibidas com a perda do direito ao amparo financeiro coletivo; a educação das crianças deveria ser atraente, implicando sessões breves e prazerosas, com variação nos conteúdos e na combinação de temas ligados à agricultura e à manufatura; a ênfase na educação seria grande, ainda mais que as diferentes tarefas da colônia seriam destinadas aos membros que demonstrassem capacidade específica de execução; 
- o sentido associativo transpareceria principalmente na habitação, pois uma só edificação preencheria todas as necessidades correspondentes; o prédio teria aposentos de dimensões variadas (alugados aos colonos a preços regulados pelo custo da construção) e também refeitórios, oficinas e, mais tarde, até livraria, museu e teatro; uma única cozinha coletiva preencheria as exigências, tanto quanto uma adega, um armazém e um celeiro;

- pretendia-se criar núcleo industrial com destaque no cenário socioeconômico do Brasil, atraindo um generalizado interesse e, em decorrência, estimulando a propagação do experimento; tal propósito exigiria suficiente capacidade técnica e organizativa, um requisito a ser considerado na seleção dos colonos em território francês: a preferência era por trabalhadores capazes de construir máquinas a vapor, devendo o recrutamento já da primeira leva de migrantes privilegiar pessoas com formação em engenharia e familiarizadas com a construção de máquinas, além de metalúrgicos, maquinistas e contramestres, entre outros; num país de escassas atividades industriais, esses atributos representariam benefício certo, ainda mais pelo significado das máquinas a vapor para os transportes e as comunicações num litoral tão extenso como o brasileiro;

- as atividades produtivas seriam sustentadas por um banco próprio, operando simultaneamente como caixa econômica e caixa de desconto; dispondo das colheitas e das mercadorias produzidas, o banco faria adiantamentos que permitiriam aos colonos aguardar o melhor momento para as vendas; o banco também disponibilizaria recursos segundo a habilidade e a conduta dos demandantes, acudiria financeiramente os necessitados e faria a distribuição da terra, pois esta, embora indivisa, seria objeto de arrendamento anual entre colonos ou grupos de colonos.

A parte final da carta, inegavelmente apoteótica, é eloquente sobre o utopismo incrustado na proposta.

Possamos em breve ver erguer-se e florescer a primeira colônia societária! A fama da venturosa existência que aí vivermos excitará todas as atenções, e o contágio do nosso exemplo chamará em breve em redor de nós numerosos imitadores. As artes e a poesia, frutos da ventura social, brotarão em 
breve no meio de nós; a associação tornará fáceis todas as grandes empresas, extinguirá toda a discórdia, e dirigirá para a produção as forças que hoje se destroem pelo choque dos interesses. [...] Enfim, a fama de tão bela mudança atravessará o Atlântico. Os povos da velha Europa, que sofrem, respirarão um momento em seu leito de dores. Se atualmente atravessam eles aos milhares os mares em busca de algum alívio a seus males, quem poderá dizer que febre de emigração os acometerá quando souberem que o grande problema da felicidade social está entre nós resolvido ${ }^{17}$.

Essa declaração de propósitos repercutiu junto ao ministério imperial, tanto que, intermediado por um ministro, o Dr. Mure logrou entregar a proposta diretamente a D. Pedro II (então ainda adolescente). Na ocasião, o médico leu um memorial em que destacava o significado da pretendida iniciativa para o Brasil e para o governo do jovem monarca. O desdobramento mais importante foi a permissão para que Mure embarcasse num navio da Marinha de Guerra rumo à capital da Província de Santa Catarina, com orientação ao governo local para que lhe fosse concedido o apoio necessário à escolha de um lugar para a colônia. De fato, em ofício de 13 de janeiro de 1841, ao Juiz de Paz de São Francisco, com cópia para as mesmas autoridades em Porto Belo e Itajaí, o presidente da província informa sobre a viagem do Dr. Mure, frisando:

[...] manda o Governo de S. M. o Imperador recomendar para que lhe facilitem os meios de visitar o litoral e as margens dos rios navegáveis a fim de escolher lugar [...] para a mencionada fundação em terrenos que estejam devolutos, e ditos à beira-mar ou rio. Recomenda a V. Mce. o dito Doutor e lhe ordena, que quanto de sua autoridade dependa o auxílio, lhe dê todas as indicações precisas para ele poder achar e reconhecer nas margens de todos os rios e à beira-mar um terreno para o fim indicado ${ }^{18}$.

Após percorrer algumas áreas ao sul da província, Mure seguiu para o norte, rumo a Itajaí e, depois, a São Francisco do Sul. As condições dessa

17 Carta do Dr. Mure publicada pelo Jornal do Commercio (RJ) em 17/12/1840:2, na Coluna "Colonização" (Biblioteca Nacional).

18 Ofício do Presidente da Província de Santa Catarina ao Juiz de Paz de São Francisco, com cópia para os juízes de Porto Belo e Itajaí, em 13/01/1841 - Registro: Do Presidente da Província para Juízes de Paz (Arquivo Público de Santa Catarina). 
última região determinaram a decisão do francês. Em carta que o Jornal do Commercio publicou, em 27 de março de 1841 (transcrita em BOITEUX, 1944), Mure indicou a exata localidade escolhida: a Península do Saí. Aparentemente, lideranças políticas locais compartilhavam o ponto de vista de que se tratava de opção adequada. Ofício da Câmara Municipal de São Francisco ao Presidente da Província, redigido com base nas deliberações da sessão extraordinária de 8 de março de 1841, assinalava que, na Península do Saí, ainda restavam "alguns pequenos terrenos devolutos [...]", de modo que aí poderia ter "lugar o grande estabelecimento da Colônia Industrial que o Dr. Mure se propõe a fundar [...]"19.

$\mathrm{Na}$ referida carta ao Jornal do Commercio, Mure descreve a localidade escolhida, dizendo-a

[...] coberta de boas madeiras de construção, [...] [com] as melhores matas e grande número de cascatas, tão necessárias para um emprego industrial [...]. Quanto à terra [...], reúne todas as vantagens que eu podia desejar e que achei separadas em outras partes, e tudo o mais [...] pareceria [...] [indicar a área como apropriada] para a fundação da colônia societária ${ }^{20}$.

Note-se que essa avaliação é condizente com as impressões de Saint-Hilaire (1953) sobre a área de São Francisco, colhidas por ocasião da sua passagem pelo local no ano de 1820; tratava-se, segundo esse explorador, de "região fertilíssima, onde se não precisa de tanto esforço, como na Europa, para a conquista do bem estar [...]” (pp. 98-99). Mure mencionou uma liderança local, o Coronel Camacho - a quem o governo provincial havia concedido direitos sobre terras para uso agrícola - que se teria entusiasmado com o projeto a ponto de se declarar disposto a abrir mão de parte daqueles direitos em prol da colônia. Uma correspondência de Mure com o presidente da província, relatando os resultados da viagem e agradecendo o auxílio do

19 Ofício da Câmara Municipal de São Francisco para o Presidente da Província de Santa Catarina, em 08/03/1841. Livro de Ofícios da Câmara Municipal, 1841:251252 (Arquivo Público de Santa Catarina).

20 Carta publicada pelo Jornal do Commercio em 27/03/1841, apud BOITEAUX, 1944:58. 
governo, também salientou tal disposição do Coronel Camacho, qualificando-o de indivíduo com "generosidade e patriotismo iluminado" ${ }^{21}$.

De retorno ao Rio de Janeiro, Mure encontrou-se de novo com D. Pedro II para entregar documento relatando a expedição, com observações sobre o alcance, inclusive político, da iniciativa proposta - sendo sugerida uma repercussão positiva na grande região cujo extremo sul vivenciava a Guerra dos Farrapos. O relato abriu caminho para a solicitação de apoio financeiro ao governo do Brasil, indicado como indispensável à viabilização da iniciativa colonizadora. Em julho de 1841, os parlamentares assentiram que fossem destinados, no orçamento do Ministério Imperial, sessenta e quatro dos oitenta contos de réis inicialmente pedidos por Mure, a título de auxílio para instalar a colônia no Saí.

Os esforços de Mure foram coroados no início de dezembro de 1841 com a assinatura de um contrato, transcrito na íntegra em Boiteux (1944), que estabelecia as condições para a criação e o funcionamento da colônia.As partes contratantes eram o Dr. Mure e, representando o Estado brasileiro, o Ministro Encarregado dos Negócios do Império. Seu teor desdobrava-se em catorze tópicos que identificavam o objeto da celebração e apontavam as obrigações, além de discriminar e destinar os recursos disponibilizados pelo governo. Não se tratava de recursos doados, mas de adiantamento de fundos que passariam a ser reembolsados quando a colônia exibisse sustentabilidade, devendo qualquer descumprimento dos termos contratuais provocar sequestros anuais de partes da produção até a restituição integral. Merecem realce os itens sobre proibição de compra e uso de escravos, confinamento dos colonos ao espaço do empreendimento, para fins de trabalho, e interdição ao comércio com o exterior até que os colonos se naturalizassem brasileiros. Por último, estipulava-se que o governo poderia inspecionar a colônia sempre que desejasse verificar o cumprimento dos termos contratuais, o que exigia livre acesso a todos os documentos e os registros existentes.

21 Uma carta sobre a colonisação do Sahy. Revista Trimensal do Instituto Histórico e Geográfico de Santa Catarina, v. III, 1914:13-16. 
A assinatura do contrato ocorreu poucos dias antes da chegada do navio com os cem primeiros colonos ao Rio de Janeiro. Isso pode ser interpretado como sinal de ousadia ou imprevidência dos organizadores da viagem, já que o embarque fora providenciado sem que tivesse ocorrido o comprometimento formal do governo brasileiro. Logo após a chegada, o Presidente do Tribunal do Tesouro Público Nacional

[...] remete ao Sr. Inspetor da Tesouraria da Província de Santa Catarina a cópia do Decreto de 11 deste mês com as condições relativas ao estabelecimento de uma Colônia Industrial de franceses na dita Província, a fim de que pela parte que lhe toca lhe dê o devido cumprimento $[\ldots]^{22}$.

\section{Da utopia à frustração}

Não obstante o interesse de todas as partes envolvidas, não faltaram problemas nos passos iniciais do projeto colonizador. Ao menos em parte, esses problemas guardaram relação com o que houve na França, durante a estada de Mure no Brasil.

No primeiro semestre de 1841, a Union Industrielle fora modificada pelos fundadores que tinham permanecido na França. A mudança implicou a entrada de pessoas com princípios divergentes dos de Mure (o médico dizia serem saint-simonistas, com ideias opostas às dos fourieristas) e ocorreu à revelia da opinião deste, que se encontrava no Brasil.Tal fato desgostou Mure e comprometeu a sua confiança nos sócios. De outra parte, dois destes (Jamain e Derrion), ao chegarem ao Rio de Janeiro com os primeiros colonos (associados da Union), souberam que Mure conseguira a concessão das terras na Península do Saí em seu próprio nome, e não para a aquela associação. Descobriram também não terem sido informados sobre a maior parte dos termos do contrato com o governo imperial. Isso aconteceu logo após Mure ter partido para São Francisco do Sul, sem se comunicar com eles, deixando-os na capital em companhia de vários colonos, cujos pertences, porém, seguiram viagem.

22 Ofício do Tesouro Público Nacional para o Presidente da Província de Santa Catarina - n. 81, em 23/12/1841 (Arquivo Público de Santa Catarina). 
De outro lado, uma parte dos franceses que seguiram para a Província de Santa Catarina decidiu abandonar, já na chegada, o grupo sob a liderança de Mure, levando consigo parte do material trazido a bordo, para cuja recuperação o médico requisitou ajuda policial. O desligamento refletiu desagrado com o que ocorrera no Rio de Janeiro e com as condições de recepção em São Francisco, que denotavam um deficiente preparo. Note-se que a possibilidade de que pudessem ocorrer problemas de recepção tinha sido pressentida na província. Em correspondência de 30 de dezembro de 1841 ao Ministério do Império, o presidente provincial advertiu: se o Dr. Mure "não tem preparado depósito de víveres, ou não os trás [sic] ao menos, acho que houve precipitação na vinda dos colonos, e receio algum descontentamento de parte deles, porque o país poucos recursos oferece"23. Já tensa, a atmosfera deteriorou-se ainda mais com as crescentes evidências de indefinição e desorientação sobre o comando da colônia, agravando a insatisfação dos outros colonos, que ameaçaram com dissidência. A chegada a São Francisco, dias depois, dos sócios que tinham sido deixados no Rio de Janeiro (acompanhados de outros societários, que também haviam ficado), acirrou ainda mais os ânimos. Por terem sido responsáveis pela seleção dos viajantes na França, Jamain e Derrion mobilizaram facilmente os descontentes, os quais, a partir de uma assembleia, passaram a desconsiderar os direitos de empreendedor de Mure e ocuparam a sede da colônia, forçando o médico a transferi-la. Só uma minoria aceitou os termos do contrato com o governo brasileiro, permanecendo o restante - a maioria de descontentes - em situação que as autoridades não sabiam como tratar.

Assim, o empreendimento no Saí nasceu marcado por fortes desavenças, com renhida disputa de poder. É eloquente a esse respeito a intensa correspondência, em janeiro e fevereiro de 1842, entre o presidente da província, o Juiz de Paz de São Francisco, a Câmara desse município e os líderes dos franceses, Mure de um lado,Jamain e Derrion de outro. Bastante significativas sobre o desconforto da administração provincial são as cartas entre o Presidente e o Ministro dos Negócios

23 Carta do Presidente da Província de Santa Catarina ao Ministro dos Negócios do Império, em 30/12/1841:60, Livro de Registros n. 112 (Arquivo Público de Santa Catarina). 
do Império, evidenciando dúvidas até sobre a questão do acesso dos colonos às terras concedidas.

Cumprirá $[\ldots]$ que se determine à custa de quem há de ser feita a transação e demarcação [...]. [P]reciso queV. Excia. se sirva dizer-me [...] se é o governo ou o Dr. Mure que deve ser considerado o locatário dos serviços [...].Também me parece indispensável que a administração municipal saiba se a concessão do terreno é feita ao Dr. Mure, ou se ele é só o encarregado da distribuição aos colonos, e, neste caso, a tarifa, porque ele se há de regular no praticá-la, e com que direito ficará cada colono à porção que lhe for distribuída e sob que condições ${ }^{24}$.

Observa-se não só desinformação na província sobre a maneira de encaminhar as questões referentes à colonização, como também aumento da inquietação local com a tensão decorrente das desavenças entre os recém-chegados. Numa sequência de cartas ao Ministro dos Negócios do Império, o presidente da província aborda o assunto, chegando a problematizar, em missiva de 8 de fevereiro de 1842, o próprio sentido da proposta colonização. Nas entrelinhas, há mesmo uma crítica ao Ministério quanto à definição dos termos contratuais acertados com o Dr. Mure.

Parece-me que V. Excia., à vista dos estatutos, que também lhe envio, da Sociedade União Industrial, se convencerá de que jamais será admissível no Brasil um estabelecimento que tenha que ser regido por estatutos semelhantes, em que se encontram doutrinas as mais perigosas, e princípios não só subversivos de toda a ordem, como contrários às instituições que nos regem, sendo esta mais uma razão poderosíssima para não admitir-se no Saí os que abraçaram e professam tais doutrinas e princípios, e que ao menos os não abjurarem por meio de um novo contrato. Não me compete julgar do mérito ou demérito do que apresenta o Dr. Mure, mas creio que ele carece ser reformado, principalmente na parte relativa aos direitos e deveres dos colonos e do empresário, pois me parece que os direitos dos primeiros não estão bem definidos, quando os do último têm amplidão demais, parecendo-me ainda que deverá ser mais expressa, em tal contrato, a direção que o Governo Imperial tem na empresa, o que a ele é devido,

24 Ofício do Presidente da Província de Santa Catarina ao Ministro dos Negócios do Império em 08/01/1842:61, Livro de Registro - Do Presidente da Província, n. 113 - 1839/44 (Arquivo Público de Santa Catarina). 
fazendo-se desaparecer de que se apresenta a idéia de que é o Doutor Mure quem dá terras e fornece fundos. Acerca do sobredito contrato, é minha opinião que ele devesse ter sido visto e aprovado porV. Excia. antes da vinda do empreendimento $[\ldots]^{25}$.

A cisão do grupo fez com que parte dos franceses ficasse na Vila de São Francisco, em condições deploráveis. A proibição de trabalhar fora da colônia dificultava sua situação, mas as próprias possibilidades de trabalho eram muito escassas localmente, como constatou, em 1858, Avé-Lallemant (1953:178) sobre belgas trazidos por agentes de emigração daquele país, com a promessa de emprego e remuneração: "não acharam ocupação com salário de quinze francos [como se prometera], nem de seis; ao contrário [...], não acharam trabalho nenhum. Os pobres diabos tinham fome". A disputa entre os franceses evoluiu a ponto de canalizar a atenção do Juiz de Paz local e mesmo do presidente da província, que solicitou ao Ministro do Império a concessão de terras devolutas na Península do Saí, além de recursos em adiantamento, para que os dissidentes se instalassem por conta própria, como tinham pedido. A administração provincial, respaldada em decisão do governo brasileiro, reafirmou os direitos de Mure, ao mesmo tempo em que procurou agir para conciliar os franceses.

Tanto a posição do médico foi sustentada pela ação governamental que seus ex-sócios tiveram de comprar as terras solicitadas para os dissidentes, devido à recusa do governo em concedê-las. Nessas terras foi instalada, em abril de 1842, a colônia do Palmital, com cerca de quarenta colonos. Mure, apesar dos problemas (ou por causa deles, que exigiam rápida demonstração de eficiência e controle da situação), acelerou a instalação do que ficou conhecido como Colônia do Saí, de modo que, também em abril de 1842, a maioria dos que permaneceram sob sua liderança se encontrava estabelecida. Cabe indicar que, de todos os imigrantes embarcados na França, um número expressivo acabou não se engajando no empreendimento. A maioria dispersou-se, quer na chegada ao Rio de Janeiro, quer na região de São Francisco do Sul, tendo alguns rumado para outras paragens (o Uruguai, por exemplo).

25 Carta do Presidente da Província de Santa Catarina ao Ministro e Secretário de Estado dos Negócios do Império, em 08/02/1842:64 - Livro de Registros - Rg. n. 119 (Arquivo Público de Santa Catarina). 
De toda maneira, uma vez criadas, as colônias do Saí e do Palmital apresentaram um relativo progresso. Mais do que isso, lograram até estabelecer, a despeito das turbulências iniciais, alguma relação entre si, fruto de iniciativa do governo da província em promover um contrato entre ambas.

Carta de Mure publicada pelo Jornal do Commercio, em 23 de junho de 1842, dizia que, em poucos meses, a Colônia do Saí registrara várias iniciativas. Os trechos mais relevantes encontram-se abaixo.

Ter visto o Saí há seis meses e revê-lo hoje, não seria por certo um espetáculo vulgar para o viajante mais indiferente. Supondo que tomasse a estrada em frente à vila, $[\ldots]$ veria, em primeiro lugar, [...] uma forja quase sempre acesa, onde se fabrica e concerta a numerosa ferramenta que exigem os trabalhos da colônia. Os mesmos habitantes dessa costa e os operários brasileiros que trabalham com os colonos franceses, recorrem a essa forja [...].

Se entramos terra a dentro, acharemos em bom estado a estrada que ainda há pouco era quase impenetrável. Uma boa parte dela já indica que uma população ativa a frequenta [...]; mas em três quartos de hora de caminho chegamos aos limites da mata virgem. É aí que acaba a estrada antiga e que começa o novo trabalho colonial; é aí que se abriu uma vasta estrada, que se lançaram pontes, que se entulharam barrancos, que subidas íngremes se tornaram suaves [...].

Depois de flanquear esta bela obra, $[\ldots]$ divisamos $[\ldots]$ algumas casas. É o nosso primeiro campo, é o nosso primeiro estabelecimento [...].

O campo deu já uma colheita satisfatória de feijão e as dará ainda mais ricas quando os nossos agricultores tiverem adquirido a necessária experiência local. A casa principal é de barro coberta de palha e pode conter de 15 a 20 famílias.

Entremos porém de novo no mato virgem. É aqui que começa o verdadeiro trabalho colonial. O Saí pequeno com suas numerosas cascatas, [...] é bem digno de tentar a ambição de trabalhadores europeus para quem a força motriz é tão preciosa [...]. Era de mister abrir um caminho para esse rio, mas só a idéia de o tentar era uma temeridade [...]. Desanimei por um momento e julguei que melhor seria abrir a navegação do rio até o mar, do que fazer essa légua de estrada por cima dos precipícios [...]. Principiamos portanto trabalhos hidráulicos e uma represa no Saí.

Através de escabrosos carreiros, chegamos no rio onde devíamos trabalhar [...]. Esta estrada, no princípio tão terrível, tornou-se-nos mais familiar; transitou-se, suavizou-se, atalhou-se em alguns pontos, e por um 
dia disse-me um dos nossos societários: 'Dai-me braços, dinheiro e tempo, e eu farei o caminho do Saí. Há dois meses que isto se passou, e hoje a estrada está concluída.

Dezoito pontes [...] foram lançadas sobre torrentes e precipícios, e sobre quase todos os pontos pode rodar sem obstáculos um carro de bois. [...]

Penso pois [...] que não temos perdido o nosso tempo. Penso também que a cada instante de nossa existência colonial o terreno que ocupamos apresentará um aumento de valor igual aos adiantamentos que temos recebido. De cada lado da estrada que abrimos, já a exploração das madeiras nos oferece abundantes recursos, e todos os dias preparamos novos recursos para os colonos que esperamos. O auxilio do governo nos é necessário, mas ouso dizer que a alguma glória teremos direito se somente com esse auxílio pudermos fazer o que em outras e melhores circunstâncias custou quinze e vinte vezes mais ${ }^{26}$ (negrito adicionado à citação).

Também em junho de 1842 o Inspetor Mafra, designado pelo governo da província para acompanhar o andamento da colonização, enviou ao Ministro dos Negócios do Império um relatório em que reiterava muitas dessas informações de Mure, inclusive elogiando a qualidade do que observou e a engenhosidade dos franceses. Mais do que isso, assinalou que, se mais recursos estivessem disponíveis, tanto a represa quanto a serraria mecânica em construção já estariam prontas. O relatório também informou sobre a Colônia do Palmital. O Jornal do Commercio publicou esse relatório em 17 de julho de 1842, cujos trechos mais importantes para o propósito do artigo estão abaixo.

Agora direi a V. Ex. o que vi em ambos os estabelecimentos.

Quanto ao Saí.

Como o terreno devoluto concedido para o estabelecimento da colônia não tem saída para o mar, senão pelo rio Saí, que não é navegável no sítio onde deve ficar a colônia, e sendo indispensável que os colonos tivessem mais à mão os recursos de que carecessem nos primeiros tempos, o Dr. Mure ocupou uma ilhota deserta, denominada Alvarenga, a duzentas braças da margem esquerda do rio de $\mathrm{S}$. Francisco, e aqui erigiu duas cabanas, que lhe servem de depósito de víveres. No continente fronteiro a esta ilhota e à vila comprou, à margem do rio, um sítio que tem sofrível

26 Carta do Dr. Mure, publicada pelo Jornal do Commercio (RJ) em 23/06/1842:1-2 (Biblioteca Nacional). 
casa de vivenda, e algumas terras de cultura e pastagens. Na casa está montada, e em atividade, uma forja, e principia a ter no pasto algum gado; mas, achando-se os fundos deste sítio ainda distantes dos limites do terreno concedido, arrendou por seis anos outro terreno que confronta com a colônia, e neste erigiu uma casa bastante espaçosa, que denomina Picot, onde há um forno, e que habitam três famílias e os colonos empregados no desmatamento e abertura do caminho. Em torno desta casa há uma derrubada que já tem uma horta e um bananal, e onde se plantaram diversos grãos vindos da Europa, mas que pouco produziram [...].

Até este ponto há 450 braças de caminho, denominado Büchele, melhorado e feito para a colônia, e transitável por carros.

Daqui até às nascentes do Saí, onde deve ser o centro da colônia, há 2.400 braças de caminho, em continuação daquele, chamado Mangin, todo aberto e feito de novo, e em toda extensão de 2.850 braças, há dezoito pontes e estivas feitas com bastante solidez, ligando algumas das primeiras às quebradas de outeiros, para estabelecer o nivelamento.

A direção deste caminho foi bem escolhida, e ele está bem acabado; fizeram-se grandes trabalhos em arrancar e destruir rochedos que o obstruíam, e, me parece, não só que foram bem empregadas as quantias que com ele se despenderam, como que esta despesa é muito inferior à importância da obra; porquanto, agora já está descoberta e reconhecida grande parte do terreno que a colônia há de ocupar; já os colonos que chegarem penetrarão desassombrados no interior, e acharão posições à escolha onde se estabeleçam, tendo já franca uma via para a saída dos seus produtos.

Na mesma posição, e nas nascentes do Saí, se está construindo um dique para represar as águas vertentes das serras, e fazê-las sair pela comporta, afim não só de aprofundar o nível (...) do rio e torná-lo navegável desde aquele ponto, mas também de desobstruí-lo. Estão feitos os paredões do dique, trata-se de cavar o reservatório ou tanque, e de fazer a comporta, cujo desenho vi, e me pareceu de uma construção engenhosa, e que desempenhará cabalmente o fim. (...).

Todos os trabalhos que deixo referidos têm sido feitos com o concurso de jornaleiros do país, e nem poderia ser de outro modo, visto que o Dr. Mure só tem consigo vinte e uma pessoas [...].

$[\ldots]$

Inspecionei os livros de contabilidade da colônia do Saí, que achei escriturados em regra. A receita por ora não consta senão dos socorros dados pelo governo imperial à colônia $[\ldots]$.

$[\ldots]$ 
Quanto ao estabelecimento do Palmital.

Está este $[\ldots]$ a sete léguas da vila de S. Francisco; mas, em razão da configuração do terreno intermédio, quase que se toca com o do Saí, sendo praticável abrir-se entre os dois uma comunicação que está projetada [...].

Aqui há casa de vivenda pertencente ao sítio, algum arvoredo e pastagens, que já existiam.

Como ligados a este estabelecimento, contam-se 42 colonos de toda idade e sexo; mas quatro continuam a residir na vila, e, provavelmente, nunca se reuniram aos do Palmital.

Os colonos do Palmital, que para ali foram há 2 meses, começaram os seus trabalhos dando-se a construções navais, por ora em pequena escala; estavam a concluir um lindo escaler de 18 pés de quilha, e tinham pronto o estaleiro e preparavam as madeiras para um iate de 60 pés. Este gênero de indústria pode ser muito produtivo aos colonos e profícuo ao país, porque entre eles há artistas hábeis, e não se negam a admitir discípulos brasileiros. Também tratavam de construir uma olaria, de montar uma forja e fabricavam carvão; mas nada havia ainda feito em agricultura.

Neste estabelecimento há, por ora, maior número de obreiros, e mais perfeitos que no Saí, mas não estão tão unidos e submissos como os deste.

Tenho concluído o presente relatório; por ele teráV. Ex. visto que pouco temos ainda, além de esperanças, em colonização francesa; mas estão lançados os fundamentos, existe o núcleo, e é de crer que ela vingará, e prosperará com a chegada dos que estão engajados $[\ldots]^{27}$ (negrito adicionado à citação).

No final de 1842 - pouco menos de um ano após o início da colônia - um observador louvava o que se fizera no Saí, corroborando informações de Mure e do Inspetor Mafra. Todavia, salientava que os imigrantes - engenheiros, maquinistas, carpinteiros, entre os de outras profissões "urbanas" - envolviam-se principalmente com atividades ligadas à terra, em descompasso com suas origens ocupacionais. Isso não só repercutia nos resultados obtidos, como representava desperdício de capacidade e talento. As impressões desse observador, Fernando Antonio de Miranda, foram publicadas pelo Jornal do Commercio em 26 de fevereiro de 1843 . Os principais trechos encontram-se abaixo.

27 Relatório do Inspetor José da Silva Mafra, publicado pelo Jornal do Commercio (RJ) de 17/07/1842:1, Coluna "Parte Official”" (Biblioteca Nacional). 
Ofereceu-nos a colônia uma fiel imagem dos fatos referidos pelo Illm. Inspetor da mesma, em seu último relatório, e pelo mesmo empresário, em suas correspondências publicadas no Jornal do Commercio, porém com a diferença, que provém do andar do tempo, de um [...] aperfeiçoamento contínuo.

A forja que já existia acha-se hoje muito mais animada e provida de encomendas e de meios de trabalho. O Sr. Labbé, que a dirige, mostrou-nos grande quantidade de carvão fóssil, ferro, aço e ferramenta de toda a qualidade. Os moradores de todo o litoral concorrem [...] com suas encomendas, e agora vai-se dar princípio às ferragens de um barco que um da vila mandou construir.

Mais adiante vimos uma olaria de tijolos e vários estabelecimentos agrícolas que o Illm. Sr. Mafra não mencionou em seu relatório por não existirem ainda (...).

A casa principal onde descansou o digno inspetor da colônia já não é aquela que viu e descreveu. A abertura de caminhos, o aumento das derrubadas, a ereção de casas, o acréscimo da povoação tem feito dela um centro de atividade que, no mês de junho deste ano, não se podia esperar.

Enquanto nos caminhos de que acabo de falar, não posso deixar de manifestar minha admiração [...].

Agora o caminho Mangin, no qual o inspetor da colônia passou a pé, dá passagem a carros que duas vezes na semana vão além do Saí levar mantimentos aos constantes trabalhadores que ali tratam de estabelecer uma serraria.

$\mathrm{Na}$ extremidade do caminho do Saí estão estabelecendo uma serraria mecânica, que já está muito adiantada, e que para o meio de fevereiro acharse-á em plena atividade. Já estaria há muito acabada, se a falta de recursos não houvesse demorado esta empresa, do que depende a sorte da colônia.

Foi a este lugar somente, onde estavam fabricando uma represa, $[. .$. que chegou o Sr. Mafra; porém atualmente este ponto é apenas a metade do território aberto [...]. Ali principia um caminho de duas mil braças, que ainda não presta para carros, mas que é muito bom para peões e até para cavalos.

Este caminho acaba no centro da península, no cume de um morro, [lugar] [...] destinado para a construção do núcleo principal.

Parte do caminho atravessa as imensas [...] florestas que cobrem a península do Saí; mas [...] à direita e esquerda avistei [...] casas de famílias coloniais, feitas com os mesmos materiais do lugar [...].

Essas casas estão circundadas de vastas derrubadas feitas pelos mesmos colonos, [...] e que já principiam a dar colheitas; na última daquelas vi uma 
grande criação de porcos que por todos os meios o Dr. Mure procura naturalizar nos matos do Saí.

Em toda a parte encontramos a mais franca e sincera hospitalidade, e os colonos pareciam muito satisfeitos de sua sorte. Os mais antigos [...] já escreveram para a França chamando seus filhos e convidando seus conhecidos a partilharem sua sorte. Então o bom resultado da colônia já não seria duvidoso, se o governo continuar a proteger este interessante estabelecimento.

Depois deste ligeiro esboço, passo [...] a expor algumas reflexões que me foram inspiradas pela minha viagem à colônia, e indicar com franqueza não só os perigos que ameaçam a prosperidade e até a existência da mesma, como também as medidas que possam contribuir para seu desenvolvimento e progresso. [...].

Achei na colônia uma fonte de perdas muito sensíveis, e que me parece digna de toda a atenção [...]; e vem a ser que as capacidades e os intentos dos indivíduos acham-se geralmente empregados de uma maneira bem pouco vantajosa em seus resultados.

Vi na colônia do Saí carpinteiros ocupados em lavrar a terra, curtidores em plantar, engenheiros a fazer valas, maquinistas em derrubar paus, finalmente fabricantes de máquinas a vapor rebocando paredes. É verdade que nisso foi algum tanto culpado o empresário, que ao princípio devia mandar vir de França lavradores, para só depois chamar artistas e maquinistas; porém talvez não tenha ele toda a culpa, pois que deu à sua colônia o título de Colônia Industrial, esperando, quer do governo, quer dos particulares, encomendas de máquinas que deviam dar um proveito muito maior que qualquer trabalho agrícola. [...].

Entretanto, faltando as encomendas industriais, forçoso foi dedicar-se à agricultura, e foi o que fizeram os colonos do Saí [...]; porém a isto chama em perda imensa para os colonos que tomaram este partido, e perda maior ainda para o Brasil [...].

Esta circunstância [...] contribuiu muito para a dispersão dos colonos vindos pelo Virginia, os quais eram, pela maior parte, artistas, e fácil era organizá-los apresentando-lhes um emprego idôneo de seus talentos. Porém, não havendo outro afazer que desse produtos imediatos, senão o de preparar madeiras, e demais pouca esperança de melhor futuro, facilmente deram ouvidos a alguns espíritos turbulentos que entre eles se achavam e ameaçavam a colônia de uma ruína completa.

Não posso também deixar de dizer que a justiça não é administrada na colônia como o devera ser nos princípios de um estabelecimento onde infalivelmente encontram-se espíritos [...] descontentes. [...] 
Tais são os principais perigos que ameaçam o porvir da colônia do Saí. Enquanto às medidas que podem tender a favorecer seu desenvolvimento, é evidente que a primeira é um suprimento mais abundante de socorros, e principalmente a encomenda de alguma construção naval ou de qualquer outro produto industrial que a colônia pode facilmente fornecer e cujo emprego fora necessário ao governo. $O$ empresário espera pela primeira embarcação vinte carpinteiros saídos do arsenal civil do Sr. C. Deirue, rico armador de Dunkerke. Esses homens $[\ldots]$ podem facilmente construir um navio em ponto grande, e introduzir no Brasil os métodos os mais aperfeiçoados da arquitetura naval na Europa. Prouvera a Deus que à sua chegada achem que fazer! Já se dispersou a reunião a mais completa que tinha vindo para o Brasil, de fabricantes de máquinas a vapor, e apenas alguns foram utilizados na fazenda do coronel Camacho, em Itapocú [...]. Dispersaram-se também doze marceneiros vindos ultimamente no bergatim Virginia. Estão para chegar construtores de navios, e também dispersar-se-ão se não encontrarem trabalho idôneo e já destinado para eles. Não é com os socorros atuais que a colônia do Saí pode fazer tais preparativos. Então o governo deve suprir ao que falta para aproveitar uma ocasião tão rara de utilizar os homens de talento que este estabelecimento atrai no Brasil $^{28}$ (negrito adicionado à citação).

Apesar da entusiasmada descrição de Mure e do otimismo do Inspetor Mafra, e, principalmente, dos avanços registrados por Fernando Antonio de Miranda, os meses seguintes foram difíceis. É ilustrativo que, já no começo de março, portanto logo após a publicação da carta deste último pelo Jornal do Commercio, o presidente da província assim se dirigisse à Assembléia Legislativa:

Às fagueiras esperanças de que vos dei parte no meu último relatório, acerca da fundação da colônia industrial francesa na Península do Saí, sucederam sérias apreensões de que não seria bem sucedido o intento, as quais, desgraçadamente, vemos quase realizadas. O Doutor Bento Julio Mure, empresário desta colônia, a quem se não pode negar variada instrução, modos afáveis e eloquência persuasiva, não se tem mostrado hábil fundador, ou não tem sido feliz na escolha dos meios a esse fim conducentes. [...] Tantas

28 Carta de Fernando Antonio de Miranda publicada pelo Jornal do Commercio em 26/02/1843:3 (Biblioteca Nacional). 
vantagens, tantos sacrificios, a proteção constante do governo provincial, pois que eu, assim como muita gente, anteolhando-se-me grandes bens, que à Província e ao Império deviam resultar desta fundação, a tenho sempre desveladamente favorecido; tudo tem sido infrutífero. Os primeiros cem colonos societários, desembarcados em janeiro de 1842, logo se desouveram entre si e com o empresário [...]. Os membros desses mesmos dois grupos, mal avindos, inconstantes, incapazes pela maior parte de qualquer trabalho permanente e penoso, têm-se dispersado, hoje poucos existem na colônia e mesmo na Província dos do primeiro transporte ${ }^{29}$.

A intuição do presidente se confirmou, tanto que em setembro foi solicitado ao Inspetor Mafra um relato sobre o quadro na colônia. Impossibilitado de se deslocar para a região, o inspetor enviou para Charles Leclerc - societário que Mure deixou como seu representante, quando se mudou para o Rio de Janeiro em agosto - um questionário com dezesseis perguntas específicas sobre os empreendimentos no Saí e no Palmital. As respostas, que compõem o "Relatório Leclerc", foram apresentadas em novembro ao presidente da província. $\mathrm{O}$ extrato abaixo dá uma ideia sobre o tom do documento. Perguntado sobre as oficinas existentes na colônia, Leclerc respondeu o seguinte, enfeixando outras observações:

Eu vo-lo direi uma vez por todas. No Saí não há nada. Os trabalhos que se fazem são à beira mar na casa Picot. Uma forja junto à praia, em atividades. Um rancho e um forno para cozer pão. Uma olaria abandonada. Um rancho ocupado por um estranho. A casa denominada Garillant - onde mora o que faz trabalhar a fábrica de socar, [...] em muito mau estado. [...] Em cima do morro [há] um rancho em bom estado, onde mora o empresário da serraria. [...] Segue-se a estrada, que começa à beira mar e vai até o Rio Saí [...]. Esta estrada não tendo serventia, cada dia se deteriora mais, já pela ruína das pontes, já pela vegetação e queda contínua de árvores que a atravancam" 30 .

29 Fala do Presidente da Província de Santa Catarina na Assembleia Legislativa em 01/03/1843:17-18. Disponível em < http://www.brazil.crl.edu/bsd/bsd/930/índex. html>.

30 Relatório de Charles Leclerc sobre a situação no Saí, apresentado ao Presidente da Província de Santa Catarina pelo Inspetor José da Silva Mafra em 07/11/1843 (Arquivo Histórico de Joinville). 
No final de 1843 o quadro era, de fato, desolador. Os dois grandes ranchos construídos perto do rio estavam em ruínas e a oficina próxima encontrava-se imprestável. Também a olaria tinha vindo abaixo, e nenhuma outra forja existia além da que fora instalada à beira-mar nos primeiros meses. Além disso, as áreas em que a mata havia sido derrubada se encontravam em estado de capoeiras, por terem sido abandonadas em grande parte. Já no Palmital, Leclerc informou existirem tão somente "mecanistas e um material considerável".

Pouco mais de um ano depois, Derrion, um dos ex-sócios de Mure que haviam liderado a cisão do primeiro grupo de colonos, instalando a colônia do Palmital, enviou relatório ao presidente da província (datado de 30 de dezembro de 1844) descrevendo a situação na Península do Saí ${ }^{31}$. Redigido em francês, sua elaboração cumpriu ordem da administração provincial para que um inventário da colônia fosse apresentado. Para o objetivo deste artigo, cabe assinalar que o documento confirma o essencial das indicações de Mure, do Inspetor Mafra e de Fernando Antônio de Miranda quanto à existência de: uma forja à beira mar em atividade, cultivos de "milho e diversos legumes", assim como "uma grande roça de cana e uma outra de feijões", além de arroz, alguns animais como bois e cavalos, casas, entre elas a Casa Picot, e outras construções cobertas de palha, equipamento para socar movido à força hidráulica, provida por um pequeno curso d'água, e uma serraria mecânica, terminada recentemente, igualmente movida à força hidráulica.

Mas Derrion também assinalou que próximo à Casa Picot estavam “os restos abandonados de uma fundição". E à beira do rio Saí, no vale correspondente ao essencial das terras dadas à colônia,

[...] se vê ainda os restos dos materiais para a construção de uma eclusa que não foi terminada [e] se vê também, nas margens, as ruínas de grandes e numerosas cabanas cobertas de palha invadidas e sufocadas pela vegetação, tendo a umidade feito apodrecer quase todas as estruturas. [...] Neste momento o terreno da concessão não está habitado; alguns colonos dirigem-se a ele periodicamente para colher o que plantaram, mas a

31 Relatório de Michel Marie Derrion sobre a situação do Saí, produzido (com redação em francês) por ordem do Presidente da Província de Santa Catarina, datado de 30/12/1844 (Arquivo Histórico de Joinville). 
distância da baía e a dificuldade dos transportes provocaram o abandono sucessivo de todos os locais que haviam sido utilizados ${ }^{32}$.

Sobre a infraestrutura, especificamente, é sugestiva essa passagem:

O caminho que liga o Vale do Saí à casa Picot é pouco praticável, a não ser que à [sic] pé. As numerosas pontes feitas de palmeiras, que atravessam as ravinas, construídas desde cerca de três anos, caem completamente ou em parte, e a recuperação seria custosa e a manutenção, dispendiosa.

Conservar caminhos e pontes, em terrenos tão íngremes, seria certamente uma tarefa quase impensável para os poucos remanescentes do sonho falansteriano na Península do Saí. Leclerc repertoriou no seu relatório não mais que trinta e oito colonos (dezesseis na colônia do Saí e vinte e dois na do Palmital), entre eles onze crianças. Derrion, no seu relato, apontou a presença de vinte e quatro ao todo, onze dos quais eram homens.

\section{Considerações finais}

Foram esses os traços mais importantes da trajetória exibida pela colonização fourierista no Saí. Gallo (2002) e Güttler (1994) sugerem que, no conjunto de viagens entre o final de 1841 e o início de 1844, mais ou menos 500 colonos deixaram a França para a referida experiência, embora Charles Leclerc tenha afirmado no seu relatório de novembro de 1843 que totalizou 236 o número de colonos chegados a São Francisco com esse propósito. No final de 1844, quando Derrion produziu o documento exigido pela administração provincial, menos de três dezenas encontram-se na área. Gallo (2002) avalia que a experiência terminou nos primeiros meses de 1846, com a ida de Derrion para o Rio de Janeiro, repetindo movimento de Mure quase três anos antes. Mas pode-se dizer que o fim acontecera mais cedo. Tendo em vista o acúmulo de problemas praticamente insolúveis, desencadeou-se debandada que não deixou de incluir o próprio Mure.

32 Ibidem. 
Como assinalado na introdução do artigo, esta pesquisa objetivou discernir as condições que cercaram a derrocada da colonização fourierista na Península do Saí. Perante outras experiências de colonização no mesmo período, caracterizadas por fluxos de europeus para a Província de Santa Catarina, o caráter efềmero daquela iniciativa é assunto que não deixa de chamar a atenção na historiografia do Brasil meridional.

$\mathrm{O}$ estudo indicou que o empreendimento nasceu marcado por fortes e incontornáveis desavenças, quer pelo desagrado de Mure em relação à forma como seus sócios franceses conduziram a Union Industrielle e o recrutamento de colonos na França, quer pela desaprovação desses sócios sobre o modo como o médico encaminhou o problema do contrato com o governo brasileiro sobre a colônia. A pesquisa sugeriu que esses desentendimentos iniciais foram decisivos para que a desconfiança se instalasse em todos os níveis: entre os colonos, entre as lideranças e por parte do governo (tanto no Rio de Janeiro como na província).

Muitos viajantes sofreram perdas materiais consideráveis por conta dos problemas ocorridos na chegada da primeira leva e durante os movimentos iniciais em São Francisco do Sul. Isso resultou em dissidências, já no começo, que rimaram com dispersão e nutriram a posterior escassez de braços para o desenvolvimento do processo colonizador. Contribuiu depois para a evasão o fato de muitos colonos terem recebido atribuições, durante os trabalhos no Saí, com as quais tinham pouca ou nenhuma familiaridade. Isso representou igualmente desperdício de competências e habilidades, sobretudo quanto às funções e às práticas que haviam figurado com destaque na proposta de colonização apresentada ao governo brasileiro, envolvendo, por exemplo, fabricação de máquinas. Este não foi um problema qualquer, pois o aceno naquela direção provavelmente se constituíra no aspecto mais sedutor do projeto aos olhos governamentais no Rio de Janeiro e na sede da província.

Esse problema da inadequada utilização da capacidade técnica de muitos colonos vincula-se à grande dificuldade representada pela incerteza, ao que parece vivenciada durante todo o curto período do experimento, sobre o escoamento dos produtos da colônia. As narrativas consultadas evidenciam falta de encomendas industriais que pudessem viabilizar o engajamento exclusivo ou majoritário dos colonos possui- 
dores dos correspondentes preparos técnico e profissional nas respectivas atividades. Sem representativas encomendas de particulares, e sem que o governo se envolvesse como comprador, tornaram-se praticamente insustentáveis, por exemplo, os planos de fabricação de máquinas a vapor em local tão distante das áreas de maior concentração populacional no país (algo que, vale assinalar, mostrou quão aguda havia sido a percepção de Fernando Antonio de Miranda, no início de 1843). Essa frustração de objetivos certamente provocou perda de entusiasmo junto aos colonos e decepção no governo provincial, tudo isso representando uma grande desvantagem para a colônia.

Assim, embora as realizações dos primeiros meses fossem enaltecidas pelos observadores, pelo que acenavam como promessa de alcance dos propósitos iniciais, as dificuldades apresentaram escalada que conduziu a um dramático e irreversível declínio da experiência fourierista. E quando os problemas evidenciaram que o risco de um rotundo insucesso era muito mais do que uma simples possibilidade, ganhou corpo a desolação entre os colonos, que procuram desvincular-se do processo, um quadro que, talvez, tem no abandono protagonizado pelo próprio Mure a sua melhor ilustração. Nos meios institucionais da província, a crítica, até então refreada pela esperança de que a vinda dos franceses pudesse, de fato, repercutir economicamente, ganhou vulto, sem deixar de lado o perfil ideológico da proposta.

Na capital do Império, o Embaixador da França no Brasil, atormentado pelo assédio de colonos franceses frustrados - Gallo (2002) indica que mais algumas dezenas chegaram ao Rio de Janeiro no primeiro semestre de 1844 - reivindicou em maio desse ano a interrupção do processo migratório junto ao governo imperial. Essa iniciativa encerrou o fluxo de deslocamentos, podendo ser vista como símbolo do término da saga fourierista na Península do Saí. Os cinco chefes de famílias presentes na área até agosto de 1844, remanescentes dos societários chegados no início do processo, tentaram convencer o governo da província de que poderiam, sob um novo contrato - mas preservando os princípios de Fourier - retomar as atividades na direção originalmente indicada. Contudo, tiveram recusado esse intento e saíram quase todos da região. Somente permaneceram, segundo S. Thiago (1995), o médico Deyrolles e, como único a deixar descendência, o escultor e marceneiro Ledoux. 
A trajetória da colonização no Saí, marcada por desavenças desde os primeiros passos e caracterizada pela brevidade e pela frustração generalizada, deixou um travo bastante amargo na memória da Província de Santa Catarina. Manoel J. d'Almeida Coelho, em livro sobre aspectos da história provincial - livro antigo, reimpresso em 1877 (COELHO, 1877) - culpou duramente o Dr. Mure, a quem acusou de ter iludido os colonos franceses com "grandes vantagens e um decantado comunismo" (p. 92). Nas entrelinhas, criticou também o governo, salientando que "concorreu o Estado com soma avultada de dinheiro e concessões de terras" (Ibidem). E nem os colonos foram poupados:

[...] tudo [...] foi infrutuosamente empregado, e assim era de esperar, por isso que não é com relojoeiros, ourives, modistas, etc., mas sim com outros homens, que podem ser povoados os nossos sertões. A abertura de estradas e canais, a navegação de rios, arroteamento de terras, o corte de madeiras, que tudo exige insanos trabalhos e incômodos, antes dos demorados gozos, não se obtêm com homens nascidos entre as delícias de Paris e Versailles (Ibidem, pp. 92-93).

\section{Referências bibliográficas}

AVÉ-LALLEMANT, R. Viagem pelo Sul do Brasil no ano de 1858. Rio de Janeiro: Instituto Nacional do Livro, 1953 [1859].

BEECHER, J. Charles Fourier: the visionary and his world. Berkeley: University of California Press, 1990.

BOISSONAT, J.“1782-1982”, L’Expansion. n. 200-201, oct. 1982:18-24.

BOITEUX, H. “O Falanstério do Saí”. Revista do Instituto Histórico e Geográfico de Santa Catarina XII, $1^{\circ}$ sem. 1944:47-90.

BUBER, M. O socialismo utópico. São Paulo: Perspectiva, 1971.

CHACON,V. História das idéias socialistas no Brasil. $2^{\text {a }}$ ed. Fortaleza: UFC/Rio de Janeiro: Civilização Brasileira, 1981.

COELhO, M. J. d'A. Memória histórica da Província de Santa Catharina. Desterro:Typ. de J. J. Lopes, 1877 (reimpressão).

ENGELS, F. Socialisme utopique et socialisme scientifique. Moscou: Progrès, 1974 [1880]. . A situação da classe trabalhadora na Inglaterra. São Paulo: Global, 1985 [1845].

FOUCAULT, M. "Retornar à história", in Arqueologia das ciências e história dos sistemas de pensamento. $2^{\mathrm{a}}$ ed. Rio de Janeiro: Forense Universitária, 2005:282-295 (Ditos e escritos II). . A arqueologia do saber. $7^{\text {a }}$ ed. Rio de Janeiro: Forense Universitária, 2007. 
FOURIER, F. M. C. El nuevo mundo industrial y societario. México, D.F.: Fondo de Cultura Económica, 1989 [1829].

FREYRE, G. Um engenheiro francês no Brasil. Rio de Janeiro: José Olympio, 1940 (Coleção Documentos Brasileiros, n. 26).

FURTADO, C. Formação econômica do Brasil.22ª ed. São Paulo: Nacional, 1987.

GALLO, I. C. d'A. “A aurora do socialismo: fourierismo e o Falanstério do Saí (18391850)". Campinas, 2002. Tese (Doutorado em História) - Universidade Estadual de Campinas.

GUARNERI, C.J. The utopian alternative:fourierism in Nineteenth-Century América. New York: Cornell University Press, 1994.

GÜTTLER, A. C. “A colonização do Saí (1842-1844): esperança de falansterianos, expectativa de um governo”. Florianópolis, 1994. Dissertação (Mestrado em História) - Universidade Federal de Santa Catarina.

KONDRATIEFF, N. D. "Las ondas largas de la coyuntura”, in KONDRATIEFF, N. D. \& GARVY, G. Las ondas largas de la economía. Madri: Revista de Occidente, 1946:1-58.

LANDES, D. S. Prometeu desacorrentado. Rio de Janeiro: Nova Fronteira, 1994.

MADDISON, A. Phases of capitalist development. New York: Oxford University Press, 1982.

MANTOUX, P. La revolución industrial en el siglo XVIII. Madri: Aguilar, 1962.

MARX, K. Le capital. Livre I. Paris: Sociales/Moscou: Progrès, 1982 [1867].

e ENGELS, F. Manifeste du Parti Communiste. Paris: Librairie Générale Française, 1973 [1848].

PETITFILS, J.-C. Os socialismos utópicos. São Paulo: Círculo do Livro, 1977.

RANGEL, I. “A história da dualidade brasileira”. Revista de Economia Política 1(4), out.dez. 1981:5-33.

S. THIAGO, R. Fourier: utopia e esperança na Península do Saí. Blumenau: Ed. da FURB; Florianópolis: Ed. da UFSC, 1995.

SAINT-HILAIRE, A. de. Viagem à Província de Santa Catharina. São Paulo: Sociedade Impressora Paulista, 1953 (traduzido do original em francês, edição de 1851).

UMA carta sobre a colonisação do Sahy. Revista Trimensal do Instituto Histórico e Geográfico de Santa Catarina, v. III, 1914:13-16.

WALLERSTEIN, I. El moderno sistema mundial, III: La segunda era de gran expansión de la economía-mundo capitalista, 1730-1850, México: Siglo Veintiuno, 1998.

WILSON, E. Rumo à Estação Finlândia ( $5^{\mathrm{a}}$ ed.). São Paulo: Companhia das Letras, 1987.

\section{Fontes Históricas}

Carta do Dr. Mure, publicada pelo Jornal do Commercio (RJ), em 17/12/1840:2-3, na Coluna "Colonização" (Biblioteca Nacional).

Carta do Dr. Mure, publicada pelo Jornal do Commercio (RJ), em 27/03/1841, apud Boiteaux, 1944:58. 
Carta do Presidente da Província de Santa Catarina ao Ministro dos Negócios do Império, em 30/12/1841:60 - Livro de Registros n. 112 (Arquivo Público de Santa Catarina).

Carta do Presidente da Província de Santa Catarina ao Ministro e Secretário de Estado dos Negócios do Império, em 08/02/1842:64 - Livro de Registros - Rg. n. 119 (Arquivo Público de Santa Catarina).

Carta do Dr. Mure, publicada pelo Jornal do Commercio (RJ), em 23/06/1842:1-2 (Biblioteca Nacional).

Carta de Fernando Antonio de Miranda, publicada pelo Jornal do Commercio (RJ), em 26/02/1843: 3 (Biblioteca Nacional).

Discours adressé à S. M. L'Empereur D. Pedro II, le 18 décembre 1841, par le Dr. Mure, à l'occasion de la présentation des premiers colons industriels, Jornal do Commercio (RJ), em 21/12/1841:1 (Biblioteca Nacional)

Discurso do Presidente da Província de Santa Catarina na Assembleia Legislativa, em 05/04/1836. Disponível em <http://www.brazil.crl.edu/bsd/bsd/930/índex.html>.

Discurso do Presidente da Província de Santa Catarina na Assembleia Legislativa, em 01/03/1838. Disponível em <http://www.brazil.crl.edu/bsd/bsd/930/índex.html> .

Discurso do Presidente da Província de Santa Catarina na Assembleia Legislativa, 01/03/1840. Disponível em <http://www.brazil.crl.edu/bsd/bsd/930/índex.html> .

Editorial do Jornal do Commercio (RJ) de 21/12/1841:1, sob o título "Colonização Industrial" (Biblioteca Nacional).

.24/12/1841:2, sob o título "A colônia societária” (Biblioteca Nacional).

Fala do Presidente da Província de Santa Catarina na Assembleia Legislativa, em 01/03/1842. Disponível em <http://www.brazil.crl.edu/bsd/bsd/930/índex. html>.

. 01/03/1843. Disponível em < http://www.brazil.crl.edu/bsd/bsd/930/índex. html>.

01/03/1844. Disponível em <http//www.brazil.crl.edu/bsd/bsd/930/índex. html>.

.01/03/1837. Disponível em <http://www.brazil.crl.edu/bsd/bsd/930/índex. html>.

Ofício do Presidente da Província de Santa Catarina ao Juiz de Paz de São Francisco, com cópia para os juízes de Porto Belo e Itajaí, em 13/01/1841 - Registro: Do Presidente da Província para Juízes de Paz (Arquivo Público de Santa Catarina).

Ofício da Câmara Municipal de São Francisco para o Presidente da Província de Santa Catarina, em 08/03/1841. Livro de Ofícios da Câmara Municipal, 1841:251-252 (Arquivo Público de Santa Catarina).

Ofício do Tesouro Público Nacional para o Presidente da Província de Santa Catarina - n. 81, em 23/12/1841 (Arquivo Público de Santa Catarina).

Ofício do Presidente da Província de Santa Catarina ao Ministro dos Negócios do Império em 08/01/1842. Livro de Registro - Do Presidente da Província, n. 113 - 1839/44:61 (Arquivo Público de Santa Catarina). 
Relatório do Inspetor José da Silva Mafra, publicado pelo Jornal do Commercio (RJ) de 17/07/1842:1, Coluna "Parte Official” (Biblioteca Nacional).

Relatório de Charles Leclerc sobre a situação no Saí, apresentado ao Presidente da Província de Santa Catarina pelo Inspetor José da Silva Mafra, em 07/11/1843 (Arquivo Histórico de Joinville).

Relatório de Michel Marie Derrion sobre a situação do Saí, produzido (com redação em francês) por ordem do Presidente da Província de Santa Catarina, datado de 30/12/1844 (Arquivo Histórico de Joinville). 